\title{
Aplikasi Dua Paket Pupuk Majemuk pada Tanaman Tebu Ratoon yang Ditanam dengan Juring Tunggal dan Ganda
}

\section{Two packages of coumpound fertilizer application on ratoon cane planted with single and double row}

\author{
Lestari* dan Djumali
}

Balai Penelitian Tanaman Pemanis dan Serat

Jl. Raya Karangploso Kotak Pos 199 Malang 65152, Indonesia

Diterima 15 September 2016/Disetujui 10 Februari 2017

\begin{abstract}
Area of ratoon cane $(R C)$ in Indonesia is more than $75 \%$ of total area of cane with productivity lower than plant cane (PC). To improve the productivity proper fertilizer application is required in accordance with the planting system used. This study was aimed to acquire a package of NPK compound fertilizer efficient for several planting systems of ratoon cane. The experiment was conducted in Muktiharjo Research Station, Pati in October 2013-September 2014. Two packages of compound

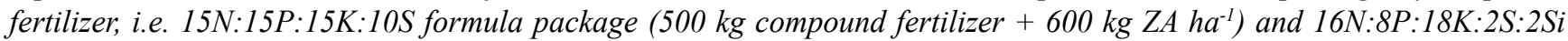

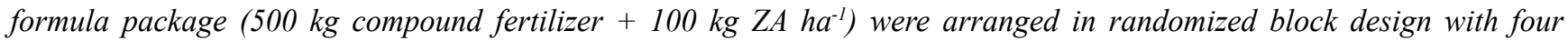
replications. Both packages were applied to two single row planting systems and two double row planting systems. The results showed that in single row planting system with both center - to - center (ctc) distances, i.e. 130 and $110 \mathrm{~cm}$, the application of 16N:8P:18K:2S:2Si formula package resulted productivity, sugar content, and sugar yield that are no different from those with 15N:15P:15K:10S formula package. However, in double row planting systems with ctc 50/170 cm, 16N:8P:18K:2S:2Si formula package increased 9.20\% sugar yield. The profit from 16N:8P:18K:2S:2Si formula package (12.07 million-14.23 million rupiah $\mathrm{ha}^{-1}$ ) in single row planting systems were lower than that of $15 \mathrm{~N}: 15 \mathrm{P}: 15 \mathrm{~K}: 10 \mathrm{~S}$ formula package (13.15 million-15.15 million rupiah $\left.\mathrm{ha}^{-1}\right)$. However in double row planting systems with ctc 50/170 cm, 16N:8P:18K:2S:2Si formula package produces profits (39.92 million rupiah ha ${ }^{-1}$ ) higher than with 15N:15P:15K:10S formula package (28.49 million rupiah $h a^{-1}$ ).
\end{abstract}

Keywords: planting-system, productivity, sugar-content, sugar-yield

\section{ABSTRAK}

Areal tebu ratoon $(R C)$ mencakup lebih dari 75\% dari total areal tebu di Indonesia dengan produktivitas lebih rendah dibanding tebu pertama (PC). Salah satu upaya yang dapat dilakukan untuk meningkatkan produktivitasnya adalah pemupukan yang tepat sesuai dengan sistem tanam yang digunakan. Penelitian ini bertujuan untuk memperoleh paket pupuk NPK majemuk yang efisien pada berbagai sistem tanam tebu ratoon. Percobaan dilakukan di KP. Muktiharjo, Pati pada Oktober 2013-September 2014. Dua paket pupuk majemuk yaitu paket pupuk formula 15N:15P:15K:10S (500 kg pupuk

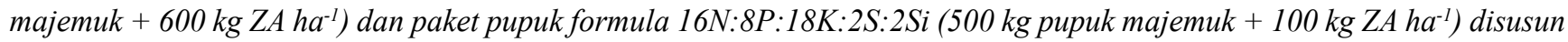
dalam rancangan acak kelompok dengan empat ulangan. Kedua paket diaplikasikan pada dua sistem tanam juring tunggal dan dua sistem tanam juring ganda. Hasil penelitian menunjukkan bahwa pada sistem tanam juring tunggal, baik dengan jarak dari pusat ke pusat (pkp) $130 \mathrm{~cm}$ maupun $110 \mathrm{~cm}$, paket pupuk formula 16N:8P:18K:2S:2Si menyebabkan produktivitas, rendemen dan hasil hablur yang tidak berbeda dengan paket formula 15N:15P:15K:10S, namun pada sistem juring ganda benih ganda pkp 50/170 cm menyebabkan peningkatan hasil hablur 9.2\%. Keuntungan yang diperoleh paket pupuk formula 16N:8P:18K:2S:2Si pada sistem tanam juring tunggal (12.07 juta-14.23 juta rupiah ha ${ }^{-1}$ ) lebih rendah dibanding paket 15N:15P:15K:10S (13.15 juta-15.15 juta rupiah ha ${ }^{-1}$ ), namun pada sistem tanam juring ganda benih ganda pkp 50/170 cm,

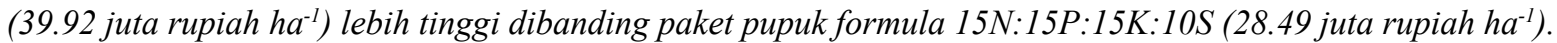

Kata kunci: hasil gula, produktivitas, rendemen, sistem tanam

\footnotetext{
* Penulis untuk korespondensi. e-mail: lestari226@gmail.com
} 


\section{PENDAHULUAN}

Target swasembada gula yang dicanangkan pemerintah menuntut peningkatan produksi, baik melalui program intensifikasi maupun ekstensifikasi. Program intensifikasi dilakukan dengan harapan produktivitas, rendemen dan hasil hablur dapat ditingkatkan. Beberapa upaya yang dapat dilakukan dalam program intensifikasi adalah pembatasan tanaman $\mathrm{RC}$, penerapan sistem tanam yang tepat dan pemupukan sesuai kebutuhan hara tanaman.

Pembatasan penggunaan tanaman RC dilakukan sebagai akibat produktivitas tanaman RC sekitar 10-20\% lebih rendah dibanding tanaman PC. Program intensifikasi memberlakukan pembatasan tanaman ratoon sampai $\mathrm{RC}$ ketiga sehingga luas areal tebu RC menjadi 75\% dari total luas tebu di Indonesia. Areal tebu RC yang masih luas menyebabkan perlunya dilakukan peningkatan produktivitas tanaman untuk mendukung swasembada gula.

Ketersediaan tenaga kerja pertanian yang terbatas menuntut diberlakukan mekanisasi dalam pengembangan tebu di Indonesia. Sistem tanam yang direkomendasikan adalah juring tunggal dengan jarak pusat ke pusat (pkp) 130 $\mathrm{cm}$. Sistem tanam tersebut dianggap terlalu lebar sehingga petani menerapkan sistem tanam juring tunggal pkp 110 $\mathrm{cm}$ dengan harapan peningkatan populasi tanaman sebesar $18 \%$ dari sistem tanam rekomendasi dapat meningkatkan produktivitas tebu. Sistem tanam juring tunggal pkp 130 $\mathrm{cm}$ dapat dikembangkan menjadi sistem tanam juring ganda bibit ganda pkp 50/210 cm dengan populasi tanaman meningkat $100 \%$ dan produktivitas meningkat $97.0 \%$ dari sistem tanam juring tunggal pkp $130 \mathrm{~cm}$. Demikian pula sistem tanam juring tunggal pkp $110 \mathrm{~cm}$ dapat dikembangkan menjadi sistem tanam juring ganda bibit ganda pkp 50/170 $\mathrm{cm}$ dengan populasi meningkat $100 \%$ dan produktivitas meningkat $120.7 \%$ dari sistem tanam juring tunggal pkp 110 cm (Djumali et al., 2014).

Rekomendasi pemupukan tanaman tebu tidak menyebutkan sumber pupuk yang digunakan. Beberapa wilayah pengembangan menggunakan pupuk tunggal dan beberapa wilayah lainnya menggunakan pupuk majemuk. Penentuan jenis pupuk dalam suatu wilayah pengembangan dipengaruhi oleh ketersediaan jenis pupuk tersebut. Belakangan ini ketersediaan jenis pupuk tunggal, terutama $\mathrm{P}$ dan $\mathrm{K}$, sulit dijumpai dan penggunaannya diutamakan untuk tanaman padi, kedelai, dan jagung. Pupuk majemuk bersifat lambat melepas (slow release) hara sehingga sangat sesuai untuk tanaman tebu. Pemupukan pada tanaman tebu diarahkan menggunakan pupuk majemuk non subsidi.

Pupuk majemuk di pasaran banyak jenisnya dengan keunggulan masing-masing. Pupuk majemuk yang umum digunakan pada berbagai jenis tanaman adalah pupuk majemuk dengan komposisi 15N:15P:15K:10S. Oleh karena itu di beberapa wilayah pengembangan tebu menggunakan jenis pupuk tersebut dalam rekomendasi pemupukan yakni sebesar $600 \mathrm{~kg}$ pupuk majemuk +500 $\mathrm{kg} \mathrm{ZA} \mathrm{ha}{ }^{-1}$ atau atau setara dengan $194 \mathrm{~kg} \mathrm{~N}, 90 \mathrm{~kg} \mathrm{P}_{2} \mathrm{O}_{5}$, $90 \mathrm{~kg} \mathrm{~K}_{2} \mathrm{O}$ dan $179 \mathrm{~kg} \mathrm{~S}^{-1}$. Jenis pupuk majemuk lain yang mengandalkan ketersediaan hara $\mathrm{K}$ dan $\mathrm{Si}$ untuk meningkatkan produktivitas tebu juga dipasarkan. Jenis pupuk majemuk tersebut berkomposisi $16 \mathrm{~N}: 8 \mathrm{P}: 18 \mathrm{~K}: 2 \mathrm{~S}: 2 \mathrm{Si}$ dengan dosis rekomendasi $600 \mathrm{~kg}$ pupuk majemuk +100 $\mathrm{kg} \mathrm{ZA} \mathrm{ha-1} \mathrm{atau} \mathrm{setara} \mathrm{dengan} 117 \mathrm{~kg} \mathrm{~N}, 48 \mathrm{~kg} \mathrm{P}_{2} \mathrm{O}_{5}, 108 \mathrm{~kg}$ $\mathrm{K}_{2} \mathrm{O}, 36 \mathrm{~kg} \mathrm{~S}$ dan $12 \mathrm{~kg} \mathrm{Si} \mathrm{ha}^{-1}$. Kedua jenis pupuk majemuk tersebut perlu diketahui pengaruhnya terhadap peningkatan produktivitas tebu, hasil hablur dan keuntungan ekonomi pada berbagai sistem tanam.

\section{BAHAN DAN METODE}

Penelitian dilakukan di KP. Muktiharjo, Pati, Jawa Tengah mulai Oktober 2013 sampai September 2014 dengan jenis tanah Alfisol dan sifat tanah tertera pada Tabel 1. Bahan yang digunakan berupa pertanaman tebu RC-1 varietas Bululawang, pupuk majemuk berformulasi $15 \mathrm{~N}: 15 \mathrm{P}: 15 \mathrm{~K}: 10 \mathrm{~S}$ dan $16 \mathrm{~N}: 8 \mathrm{P}: 18 \mathrm{~K}: 2 \mathrm{~S}: 2 \mathrm{Si}$ serta pupuk tunggal $\mathrm{N}$ bersumber dari pupuk ZA $(20 \% \mathrm{~N})$.

Perlakuan yang dicoba meliputi dua paket pupuk majemuk yakni paket pupuk formula $15 \mathrm{~N}: 15 \mathrm{P}: 15 \mathrm{~K}: 10 \mathrm{~S}$ (500 kg pupuk majemuk $\left.+600 \mathrm{~kg} \mathrm{ZA} \mathrm{ha}^{-1}\right)$ disebut paket $\mathrm{A}$ dan paket pupuk formula $16 \mathrm{~N}: 8 \mathrm{P}: 18 \mathrm{~K}: 2 \mathrm{~S}: 2 \mathrm{Si}$ (500 kg pupuk majemuk $+100 \mathrm{~kg} \mathrm{ZA} \mathrm{ha}{ }^{-1}$ ) disebut paket B. Perlakuan disusun dalam Rancangan Acak Kelompok dengan empat ulangan. Kedua perlakuan tersebut dicobakan pada empat sistem tanam yakni sistem tanam juring tunggal pkp 130 $\mathrm{cm}$ dan $110 \mathrm{~cm}$ serta sistem tanam juring ganda pkp 50/210 $\mathrm{cm}$ dan 50/170 cm. Petak perlakuan berukuran $21 \mathrm{~m}$ x 9 $\mathrm{m}$ dengan jumlah juring per petak bervariasi 15-21 juring tergantung sistem tanam yang dicoba. Dosis pupuk yang digunakan pada sistem tanam juring ganda dua kali lipat

Tabel 1. Sifat tanah tempat percobaan di Kebun Percobaan Muktiharjo, Pati, Jawa Tengah

\begin{tabular}{lrc}
\hline Sifat tanah & Nilai & Kriteria*) $^{*}$ \\
\hline pH 1:1 $\mathrm{H}_{2} \mathrm{O}$ & 4.80 & Masam \\
pH KCl 1 N & 3.90 & \\
C-Organik (\%) & 0.597 & Sangat rendah \\
N-total (\%) & 0.11 & Rendah \\
C/N & 5.40 & Rendah \\
P Bray-1 (mg kg-1) & 9.76 & Sangat rendah \\
K(Ammonium asetat 1 N pH:7) & 0.16 & Rendah \\
Na (Ammonium asetat 1N pH:7) & 0.43 & Sedang \\
Ca (Ammonium asetat 1N pH:7) & 2.29 & Rendah \\
Mg (Ammonium asetat 1N pH:7) & 0.91 & Rendah \\
KTK(Ammonium asetat 1N pH:7) & 21.43 & Sedang \\
Jumlah basa & 3.79 & \\
KB (\%) & 17.60 & Sangat rendah \\
Pasir (\%) & 11.00 & \\
Debu (\%) & 30.00 & \\
Liat (\%) & 59.00 & \\
\hline
\end{tabular}

Keterangan: *) Puslitanah (1987) 
sistem tanam juring tunggal. Aplikasi pupuk dilakukan satu kali yakni pada saat tanaman berumur 2 bulan setelah kepras dengan cara disebar di sekitar juringan dan selanjutnya dilakukan pembumbunan.

Pengamatan dilakukan menjelang panen mengambil satu rumpun tanaman per juring dan setiap petak perlakuan diambil 10 juring. Peubah yang diamati meliputi tinggi tanaman, panjang batang, diameter batang (bagian tengah), dan bobot batang/per batang. Pengamatan peubah jumlah batang per $\mathrm{m}$ juring dilakukan menjelang panen dengan menghitung batang yang mempunyai panjang lebih dari 150 $\mathrm{cm}$ pada seluruh juring di luar juring pinggir. Pengamatan produktivitas, rendemen dan hasil hablur dilakukan pada saat panen dengan memanen seluruh batang tebu, kecuali juring pinggir. Pengukuran rendemen dan hasil hablur dilakukan di PG. Trangkil, Pati. Data yang diperoleh dianalisis dengan uji t taraf 5\% pada setiap sistem tanam untuk mengetahui adanya perbedaan antara paket $\mathrm{A}$ dengan paket $\mathrm{B}$ pada setiap sistem tanam.

\section{HASIL DAN PEMBAHASAN}

\section{Aplikasi Paket Pupuk pada Sistem Tanam Juring Tunggal PKP $130 \mathrm{~cm}$}

Aplikasi pupuk majemuk paket A pada pertanaman tebu ratoon pertama dalam sistem tanam juring tunggal pkp $130 \mathrm{~cm}$ menghasilkan peubah pertumbuhan tanaman meliputi tinggi tanaman, diameter batang, panjang batang, dan bobot batang yang tidak berbeda nyata dengan pupuk majemuk paket B (Tabel 2). Hal tersebut terjadi sebagai akibat paket A memberikan tambahan hara N dan P (194 $\mathrm{kg} \mathrm{N}$ dan $90 \mathrm{~kg} \mathrm{P}_{2} \mathrm{O}_{5}$ ) yang lebih tinggi dari paket $\mathrm{B}$ (117 $\mathrm{kg} \mathrm{N}$ dan $48 \mathrm{~kg} \mathrm{P}_{2} \mathrm{O}_{5}$ ha $^{-1}$ ), sedangkan paket $\mathrm{B}$ memberikan tambahan hara $\mathrm{K}_{\text {dan }} \mathrm{Si}\left(108 \mathrm{~kg} \mathrm{~K}_{2} \mathrm{O}\right.$ dan $\left.12 \mathrm{~kg} \mathrm{Si} \mathrm{ha}{ }^{-1}\right)$ lebih tinggi dari paket $\mathrm{A}\left(90 \mathrm{~kg} \mathrm{~K}_{2} \mathrm{O} \mathrm{ha}^{-1}\right)$. Laju pertumbuhan batang tebu tertinggi terjadi pada umur 4-8 bulan (Nasir et al., 2013). Pada fase tersebut, tebu yang ditanam pada pola B (awal musim hujan di lahan kering) mengalami cekaman air. Kondisi cekaman air menyebabkan ketersediaan hara $\mathrm{K}$, Si, dan bahan organik dalam tanah sangat dibutuhkan dalam mendukung pertumbuhan batang tebu.

Hara $\mathrm{K}$ berperan untuk membantu dalam perbaikan osmotik sehingga mampu meningkatkan pertumbuhan tanaman (Farooq et al., 2009; Kingston et al., 2009). Hara Si meningkatkan silifikasi endodermal akar dan memperbaiki keseimbangan air dalam sel (Djajadi, 2013) sehingga mampu meningkatkan pertumbuhan batang tebu (Tubana et al., 2012; Mateos-Naranjo et al., 2013). Hara Si juga meningkatkan ketahanan tanaman terhadap kekurangan air melalui peningkatan fotosintesis dan aktivitas akar, menekan laju transpirasi, merangsang aktivitas ketahanan antioksidan, dan memperbaiki membran plasma (Yukamgo dan Yuwono, 2007) dan juga memperbaiki sifat fisik tanah (Brassioli et al., 2009 ). Ketersediaan hara $\mathrm{N}$ dalam tanah yang tinggi menyebabkan peningkatan serapan hara $\mathrm{N}, \mathrm{P}$ dan $\mathrm{K}$ dalam jaringan tanaman tebu (Ashraf et al., 2008; Wijaya, 2008) sehingga pertumbuhan tanaman meningkat. Hasil penelitian Wiedenfeld dan Encisco (2008) serta Inoue et al. (2009) menunjukkan bahwa peningkatan dosis pupuk $\mathrm{N}$ menyebabkan peningkatan bobot batang tebu. Demikian pula hasil penelitian Ramadhaini et al. (2014) menunjukkan adanya peningkatan diameter batang kelapa sawit akibat peningkatan hara $\mathrm{N}, \mathrm{P}$ dan $\mathrm{K}$.

Paket A menghasilkan jumlah batang per $\mathrm{m}$ juring yang dihasilkan yang tidak berbeda nyata dengan perolehan paket B (Tabel 2). Hal tersebut terjadi sebagai akibat kedua paket tersebut mempunyai keterbatasan hara tersedia yang dibutuhkan untuk membentuk jumlah batang per $m$ juring. Secara umum jumlah tanaman tebu per $m$ juring mengalami peningkatan hingga umur 3 bulan setelah tanam dan pada umur selanjutnya mengalami penurunan hingga stabil pada umur 6 bulan setelah tanam (Dev et al., 2013). Jumlah batang per $\mathrm{m}$ juring tidak hanya dipengaruhi oleh faktor genotipe namun juga dipengaruhi oleh faktor lingkungan dan perlakuan yang diberikan (Singh et al., 2007; Gana, 2008). Menurut Singh et al. (2008), jumlah batang per $\mathrm{m}$ juring dipengaruhi oleh kandungan hara $\mathrm{N}, \mathrm{P}, \mathrm{K}, \mathrm{Mg}$ dan $\mathrm{S}$

Tabel 2. Pertumbuhan, produktivitas, rendemen dan hasil hablur tebu RC-1 pada sistem tanam juring tunggal pkp $130 \mathrm{~cm}$ akibat perlakuan dua paket pupuk majemuk di KP. Muktiharjo, Pati

\begin{tabular}{|c|c|c|}
\hline \multirow{2}{*}{ Karakter agronomi : } & \multicolumn{2}{|c|}{ Paket pupuk formula } \\
\hline & $15 \mathrm{~N}: 15 \mathrm{P}: 15 \mathrm{~K}: 10 \mathrm{~S}$ & 16N:8P:18K:2S:2Si \\
\hline Tinggi tanaman $(\mathrm{cm})$ & 349.10 & 353.80 \\
\hline Panjang batang (cm) & 315.00 & 315.80 \\
\hline Diameter batang $(\mathrm{cm})$ & 2.40 & 2.41 \\
\hline \multicolumn{3}{|l|}{ Bobot batang $(\mathrm{g})$ : } \\
\hline Per batang & 1597.30 & 1507.40 \\
\hline Per meter batang & 507.10 & 477.40 \\
\hline Jumlah batang per $\mathrm{m}$ juring & 10.95 & 10.40 \\
\hline Produktivitas (ton ha ${ }^{-1}$ ) & 91.62 & 85.80 \\
\hline Rendemen (\%) & 7.13 & 7.05 \\
\hline Hasil hablur (ton $\mathrm{ha}^{-1}$ ) & 6.53 & 6.05 \\
\hline
\end{tabular}


dalam tanah, dimana peningkatan hara tersebut dalam tanah dapat meningkatkan jumlah batang tebu per m juring (Inoue et al., 2009; Shukla et al., 2009; McCray et al., 2010). Pengaruh hara terhadap pertumbuhan tanaman ditentukan oleh ketersediaan hara terendah dalam tanaman tersebut sebagaimana yang berlaku hukum minimum Leibigh. Paket A memberikan hara $\mathrm{K}$ yang rendah, sedangkan paket $\mathrm{B}$ memberikan hara $\mathrm{N}, \mathrm{P}$ dan $\mathrm{S}$ yang rendah.

Produktivitas yang diperoleh paket A tidak berbeda nyata dengan yang dihasilkan paket B(Tabel2). Produktivitas tanaman tebu merupakan fungsi dari faktor juring, bobot batang dan jumlah batang per meter juring. Dalam kondisi pkp yang sama, maka produktivitas ditentukan oleh bobot batang dan jumlah batang per meter juring (de Sousa-Vieira dan Milligan, 2005). Bobot batang dan jumlah batang per meter juring yang dihasilkan oleh kedua paket pupuk tersebut tidak ada perbedaan, yaitu masing-masing 1,597.30 $\mathrm{g}$ dan $1,507.40 \mathrm{~g}$ serta $507.10 \mathrm{~g}$ dan $477.40 \mathrm{~g}$.

Rendemen yang dihasilkan paket A tidak berbeda nyata dengan yang diperoleh paket B (Tabel 2). Rendemen tebu dipengaruhi oleh banyak faktor, salah satunya adalah jenis pupuk. Aplikasi pupuk NPK sampai dosis tertentu dapat meningkatkan rendemen dan peningkatan dosis selanjutnya dapat menurunkan rendemen tebu yang diperoleh (Dametie et al., 2012). Aplikasi $140 \mathrm{~kg} \mathrm{~N} \mathrm{ha}^{-1}$ menghasilkan rendemen tebu tertinggi dan peningkatan dosis pupuk $\mathrm{N}$ selanjutnya dapat menurunkan rendemen (Vieira et al., 2010; NagaMadhuri et al., 2011; Nurhayati et al., 2013). Adapun aplikasi pupuk $\mathrm{S}$ dapat meningkatkan rendemen tebu (Singh et al., 2008). Aplikasi pupuk Si dapat meningkatkan rendemen tebu (Matichenkov et al., 2002; Brassioli et al., 2009; Keeping et al., 2010). Paket A memberikan tambahan hara $\mathrm{N}$ lebih dari $140 \mathrm{~kg} \mathrm{ha}^{-1}$ dan K lebih rendah dan P serta $\mathrm{S}$ yang lebih tinggi dibanding paket B. Paket B memberi tambahan hara $\mathrm{N}$ kurang dari $140 \mathrm{~kg} \mathrm{ha}^{-1}$, hara $\mathrm{P}$ dan $\mathrm{S}$ yang lebih rendah serta hara $\mathrm{K}$ dan Si yang lebih tinggi dibanding paket A.
Hasil hablur yang diperoleh paket A tidak berbeda dengan paket B (Tabel 2). Hasil hablur merupakan fungsi dari produktivitas dan rendemen yang diperoleh. Produktivitas dan rendemen yang dihasilkan oleh kedua paket pupuk tersebut tidak beda sehingga hasil hablur yang diperoleh juga tidak beda (Tabel 2).

\section{Aplikasi Paket Pupuk pada Sistem Tanam Juring Tunggal $P K P 110 \mathrm{~cm}$}

Aplikasi pupuk majemuk paket A pada pertanaman tebu ratoon pertama dalam sistem tanam juring tunggal pkp $110 \mathrm{~cm}$ menghasilkan tinggi tanaman, diameter batang, panjang batang, bobot batang, dan jumlah batang per $\mathrm{m}$ juring yang tidak berbeda nyata dengan paket B (Tabel 3). Hal tersebut terjadi sebagai akibat paket A memberikan tambahan hara $\mathrm{N}, \mathrm{P}$ dan $\mathrm{S}$ yang lebih tinggi dari paket $\mathrm{B}$, sedangkan paket $\mathrm{B}$ memberikan tambahan hara $\mathrm{K}$ dan $\mathrm{Si}$ yang lebih tinggi dari paket A. Kelima jenis hara tersebut berpengaruh positif terhadap pertumbuhan tebu (Kumar dan Sinha, 2008; Otto et al., 2010; Virdia dan Patel, 2010; Nasir et al., 2013).

Produktivitas tebu yang dihasilkan kedua paket pupuk majemuk tidak berbeda nyata (Tabel 3). Hal tersebut terjadi sebagai akibat bobot batang dan jumlah batang per $\mathrm{m}$ juring yang dihasilkan kedua paket tersebut tidak berbeda nyata. Produktivitas tebu dan rendemen yang dihasilkan oleh kedua paket tersebut yang tidak berbeda menyebabkan hasil hablur menjadi tidak berbeda (Tabel 3).

\section{Aplikasi Paket Pupuk pada Sistem Tanam Juring Ganda Bibit Ganda PKP 50/210 cm}

Aplikasi pupuk paket A pada sistem tanam juring ganda bibit ganda pkp 50/210 cm menghasilkan jumlah batang per $\mathrm{m}$ juring yang lebih tinggi dan rendemen yang lebih rendah dibanding paket B (Tabel 4). Sistem tanam

Tabel 3. Pertumbuhan, produktivitas, rendemen dan hasil hablur tebu RC-1 pada sistem tanam juring tunggal pkp $110 \mathrm{~cm}$ akibat perlakuan dua paket pupuk majemuk di KP. Muktiharjo, Pati, Jawa Tengah

\begin{tabular}{lcc}
\hline \multirow{2}{*}{ Karakter agronomi : } & \multicolumn{2}{c}{ Paket pupuk formula } \\
\cline { 2 - 3 } & 15N:15P:15K:10S & 16N:8P:18K:2S:2Si \\
\hline Tinggi tanaman (cm) & 362.30 & 363.80 \\
Panjang batang (cm) & 326.20 & 327.60 \\
Diameter batang (cm) & 2.32 & 2.33 \\
Bobot batang (g) : & & 1296.90 \\
Per batang & 1389.00 & 395.90 \\
Per meter batang & 425.90 & 10.50 \\
Jumlah batang per $\mathrm{m}_{\text {juring }}$ & 10.05 & 88.24 \\
Produktivitas (ton ha ${ }^{-1}$ ) & 90.19 & 6.60 \\
Rendemen (\%) & 7.00 & 5.83 \\
Hasil hablur (ton ha $^{-1}$ ) & 6.32 & \\
\hline
\end{tabular}


juring ganda bibit ganda pkp 50/210 cm dikembangkan dari sistem tanam juring tunggal pkp $130 \mathrm{~cm}$ dengan penambahan populasi tanaman sebanyak 100\%. Hasil penelitian Djumali et al. (2016) menunjukkan sistem tanam juring ganda bibit ganda pkp 50/210 cm menerima intensitas cahaya dalam tajuk tanaman lebih besar dibanding sistem tanam juring tunggal pkp $130 \mathrm{~cm}$. Penambahan hara N, P dan S $(388 \mathrm{~kg}$ $\mathrm{N}, 180 \mathrm{~kg} \mathrm{P}_{2} \mathrm{O}_{5}$ dan $358 \mathrm{~kg} \mathrm{~S} \mathrm{ha}^{-1}$ ) yang tinggi dalam kondisi energi cahaya dalam tajuk tanaman yang tinggi mampu meningkatkan jumlah batang per $m$ juring namun diikuti oleh penurunan rendemen yang dihasilkan. Penambahan hara $\mathrm{K}$ dan $\mathrm{Si}\left(216 \mathrm{~kg} \mathrm{~K} 2 \mathrm{O}\right.$ dan $24 \mathrm{~kg} \mathrm{Si}^{-1}$ ) yang tinggi tidak mampu meningkatkan jumlah batang per $\mathrm{m}$ juring yang dihasilkan namun mampu meningkatkan rendemen yang dihasilkan.

Aplikasi pupuk paket A menghasilkan produktivitas tebu yang lebih tinggi, tetapi dengan hasil hablur yang tidak berbeda nyata dengan paket B (Tabel 4). Bobot batang yang dihasilkan kedua paket pemupukan tidak berbeda nyata sehingga peningkatan jumlah batang per $m$ juring akan meningkatkan produktivitas tebu. Adapun dalam kondisi produktivitas tebu yang rendah, peningkatan rendemen akan meningkatkan hasil hablur yang diperoleh. Hal inilah yang menyebabkan paket A menghasilkan produktivitas tebu yang lebih tinggi dan hasil hablur yang tidak berbeda nyata dengan paket B (Tabel 4).

\section{Aplikasi Paket Pupuk pada Sistem Taman Juring Ganda Bibit Ganda PKP 50/170 cm}

Aplikasi pupuk paket A pada sistem tanam juring ganda bibit ganda pkp 50/170 cm menghasilkan bobot batang yang lebih tinggi serta jumlah batang per $\mathrm{m}$ juring dan rendemen yang lebih rendah dibanding paket B (Tabel 5). Sistem tanam juring ganda bibit ganda pkp 50/170 cm dikembangkan dari sistem tanam juring tunggal pkp 110 $\mathrm{cm}$ dengan penambahan populasi tanaman sebanyak $100 \%$.
Hasil penelitian Djumali et al. (2016) memperlihatkan bahwa sistem tanam juring ganda bibit ganda pkp 50/170 $\mathrm{cm}$ menerima intensitas cahaya dalam tajuk tanaman lebih besar dibanding sistem tanam juring tunggal pkp $110 \mathrm{~cm}$ dan lebih rendah dibanding sistem tanam juring ganda bibit ganda pkp 50/210 cm karena perbedaan luas daun dan jumlah populasi tanaman. Aplikasi pupuk paket A memberikan tambahan hara dalam tanah sebesar $458 \mathrm{~kg}$ $\mathrm{N}, 212 \mathrm{~kg} \mathrm{P}_{2} \mathrm{O}_{5}, 212 \mathrm{~kg} \mathrm{~K}_{2} \mathrm{O}$ dan $422 \mathrm{~kg} \mathrm{~S}^{-1}$, sedangkan paket B memberikan tambahan sebesar $276 \mathrm{~kg} \mathrm{~N}, 113 \mathrm{~kg}$ $\mathrm{P}_{2} \mathrm{O}_{5}, 255 \mathrm{~kg} \mathrm{~K} 2 \mathrm{O}, 84 \mathrm{~kg} \mathrm{~S}$ dan $28 \mathrm{~kg} \mathrm{Si} \mathrm{ha}{ }^{-1}$.

Penambahan hara $\mathrm{N}, \mathrm{P}$ dan $\mathrm{S}$ yang tinggi dalam kondisi energi cahaya yang diterima dalam tajuk tanaman agak tinggi mampu meningkatkan bobot batang tebu yang dihasilkan disertai dengan penurunan jumlah batang per $\mathrm{m}$ juring dan rendemen yang dihasilkan. Adapun penambahan hara $\mathrm{K}$ dan $\mathrm{Si}$ yang tinggi justru mampu meningkatkan jumlah batang per $\mathrm{m}$ juring dan rendemen yang dihasilkan (Kingston et al., 2009), namun tidak mampu meningkatkan bobot batang yang dihasilkan. Hal inilah yang menyebabkan paket A menghasilkan bobot batang yang lebih tinggi serta jumlah batang per m juring dan rendemen yang lebih rendah dibanding paket $\mathrm{B}$.

Produktivitas tebu yang dihasilkan oleh kedua paket pupuk yang dicoba tidak menunjukkan adanya perbedaan yang nyata (Tabel 5). Jumlah batang per $m$ juring yang rendah diikuti oleh bobot batang yang tinggi menyebabkan produktivitas yang dihasilkan tidak tinggi dan demikian pula sebaliknya. Paket A menghasilkan jumlah batang lebih rendah dan bobot batang yang lebih tinggi, sedangkan paket B menghasilkan jumlah batang yang lebih banyak dan bobot batang yang lebih rendah sehingga diperoleh produktivitas tebu yang tidak ada perbedaan.

Aplikasi pupuk paket A menghasilkan hablur yang lebih rendah dibanding paket $\mathrm{B}$ (Tabel 5). Peningkatan rendemen pada pertanaman tebu yang menghasilkan produktivitas yang sama akan menyebabkan hasil hablur

Tabel 4. Pertumbuhan, produktivitas, rendemen dan hasil hablur tebu RC-1 pada sistem tanam juring ganda bibit ganda pkp 50/210 cm akibat perlakuan dua paket pupuk majemuk di KP. Muktiharjo, Pati, Jawa Tengah

\begin{tabular}{lcc}
\hline & \multicolumn{2}{c}{ Paket pupuk formula } \\
\cline { 2 - 3 } Karakter agronomi : & $15 \mathrm{~N}: 15 \mathrm{P}: 15 \mathrm{~K}: 10 \mathrm{~S}$ & $16 \mathrm{~N}: 8 \mathrm{P}: 18 \mathrm{~K}: 2 \mathrm{~S}: 2 \mathrm{Si}$ \\
\hline Tinggi tanaman $(\mathrm{cm})$ & $358.00 \mathrm{a}$ & $358.60 \mathrm{a}$ \\
Panjang batang $(\mathrm{cm})$ & $323.00 \mathrm{a}$ & $320.60 \mathrm{a}$ \\
Diameter batang $(\mathrm{cm})$ & $2.40 \mathrm{a}$ & $2.43 \mathrm{a}$ \\
Bobot batang $(\mathrm{g}):$ & & $1,553,60 \mathrm{a}$ \\
Per batang & $1,549,50 \mathrm{a}$ & $484.59 \mathrm{a}$ \\
Per meter batang & $479.64 \mathrm{a}$ & $17.80 \mathrm{~b}$ \\
Jumlah batang per $\mathrm{m}_{\text {juring }}$ & $19.60 \mathrm{a}$ & $151.32 \mathrm{~b}$ \\
Produktivitas (ton ha ${ }^{-1}$ ) & $166.82 \mathrm{a}$ & $7.38 \mathrm{a}$ \\
Rendemen $(\%)$ & $6.96 \mathrm{~b}$ & $11.60 \mathrm{a}$ \\
Hasil hablur (ton ha $^{-1}$ ) & $11.54 \mathrm{a}$ & \\
\hline
\end{tabular}

Keterangan: Angka-angka yang didampingi huruf sama dalam dalam satu baris berarti tidak berbeda nyata pada uji t taraf 5\% 
Tabel 5. Pertumbuhan, produktivitas, rendemen dan hasil hablur tebu RC-1 pada sistem tanam juring ganda bibit ganda pkp 50/170 cm akibat perlakuan dua paket pupuk majemuk di KP. Muktiharjo, Pati, Jawa Tengah

\begin{tabular}{lcc}
\hline \multirow{2}{*}{ Karakter agronomi : } & \multicolumn{2}{c}{ Paket pupuk formula } \\
\cline { 2 - 3 } & $15 \mathrm{~N}: 15 \mathrm{P}: 15 \mathrm{~K}: 10 \mathrm{~S}$ & $16 \mathrm{~N}: 8 \mathrm{P}: 18 \mathrm{~K}: 2 \mathrm{~S}: 2 \mathrm{Si}$ \\
\hline Tinggi tanaman $(\mathrm{cm})$ & $363.40 \mathrm{a}$ & $355.20 \mathrm{a}$ \\
Panjang batang $(\mathrm{cm})$ & $328.20 \mathrm{a}$ & $320.60 \mathrm{a}$ \\
Diameter batang $(\mathrm{cm})$ & $2.42 \mathrm{a}$ & $2.39 \mathrm{a}$ \\
Bobot batang $(\mathrm{g}):$ & & $1,410,70 \mathrm{~b}$ \\
Per batang & $1,633,10 \mathrm{a}$ & $429.83 \mathrm{~b}$ \\
Per meter batang & $508.98 \mathrm{a}$ & $19.60 \mathrm{a}$ \\
Jumlah batang per $\mathrm{m}_{\text {juring }}$ & $18.70 \mathrm{~b}$ & $179.17 \mathrm{a}$ \\
Produktivitas (ton ha ${ }^{-1}$ ) & $176.45 \mathrm{a}$ & $7.35 \mathrm{a}$ \\
Rendemen $(\%)$ & $6.83 \mathrm{~b}$ & $13.17 \mathrm{a}$ \\
Hasil hablur (ton ha $^{-1}$ ) & $12.06 \mathrm{~b}$ & \\
\hline
\end{tabular}

Keterangan: Angka-angka yang didampingi huruf sama dalam dalam satu baris berarti tidak berbeda nyata pada uji $t$ taraf $5 \%$

yang diperoleh mengalami peningkatan. Oleh karena itu aplikasi paket pupuk majemuk yang memperoleh rendemen yang rendah seperti paket A akan memperoleh hasil hablur yang rendah pula.

\section{Analisa Usahatani dalam Aplikasi Paket Pupuk Majemuk}

Hasil analisis usahatani terhadap aplikasi dua paket pemupukan pada berbagai sistem tanam tebu ratoon pertama seperti tercantum pada Tabel 6. Aplikasi pupuk paket A pada sistem tanam juring tunggal, baik pkp $130 \mathrm{~cm}$ maupun $110 \mathrm{~cm}$, memerlukan biaya (26.70-27.75 juta rupiah $\left.\mathrm{ha}^{-1}\right)$ dan memperoleh pendapatan (40.90-42.23 juta rupiah $\left.\mathrm{ha}^{-1}\right)$ yang lebih tinggi dibanding paket $\mathrm{B}(24.85-25.58$ juta rupiah $\mathrm{ha}^{-1}$ dan 37.70-39.13 juta rupiah $\mathrm{ha}^{-1}$ ). Kondisi yang demikian menyebabkan aplikasi pupuk paket A memperoleh keuntungan lebih tinggi (13.15-15.53 juta rupiah ha-1) dibanding dengan paket B (12.07-14.23 juta rupiah).

Aplikasi pupuk paket B pada sistem tanam juring ganda benih ganda memerlukan biaya (43.80-45.25 juta rupiah ha ${ }^{-1}$ ) lebih rendah dan menghasilkan pendapatan (75.00-85.18 juta rupiah $\mathrm{ha}^{-1}$ ) lebih tinggi dibanding paket A (47.40-49.50 juta rupiah ha ${ }^{-1}$ dan 74.64-77.99 juta rupiah ha $\left.^{-1}\right)$. Kondisi yang demikian menyebabkan aplikasi paket B menghasilkan keuntungan lebih tinggi (31.20-39.92 juta rupiah $\left.\mathrm{ha}^{-1}\right)$ dibanding dengan paket A (27.24-28.49 juta rupiah $\mathrm{ha}^{-1}$ ).

Tabel 6. Analisa usahatani penggunaan dua paket pupuk majemuk pada berbagai sistem tanam tebu ratoon pertama (RC-1) di KP. Muktiharjo, Pati, Jawa Tengah (dalam ribuan rupiah ha-1)

\begin{tabular}{|c|c|c|c|c|c|c|c|c|}
\hline \multirow{2}{*}{$\begin{array}{l}\text { Sistem } \\
\text { tanam }\end{array}$} & \multicolumn{4}{|c|}{ Paket formula $15 \mathrm{~N}: 15 \mathrm{P}: 15 \mathrm{~K}: 10 \mathrm{~S}$} & \multicolumn{4}{|c|}{ Paket formula $16 \mathrm{~N}: 8 \mathrm{P}: 18 \mathrm{~K}: 2 \mathrm{~S}: 2 \mathrm{Si}$} \\
\hline & $\begin{array}{l}\text { Biaya } \\
\text { pupuk }\end{array}$ & $\begin{array}{c}\text { Biaya tenaga } \\
\text { kerja }\end{array}$ & Pendapatan & Keuntungan & $\begin{array}{l}\text { Biaya } \\
\text { pupuk }\end{array}$ & $\begin{array}{c}\text { Biaya tenaga } \\
\text { kerja }\end{array}$ & Pendapatan & Keuntungan \\
\hline JT 130 & 5,850 & 20,850 & 42,228 & 15,528 & 4,050 & 20,847 & 39,127 & 14,227 \\
\hline JT 110 & 6,903 & 20,847 & 40,904 & 13,154 & 4,779 & 20,850 & 37,696 & 12,070 \\
\hline $50 / 210$ & 11,700 & 35,700 & 74,636 & 27,236 & 8,100 & 35,700 & 75,003 & 31,203 \\
\hline $50 / 170$ & 13,806 & 35,694 & 77,992 & 28,492 & 9,558 & 35,694 & 85,176 & 39,924 \\
\hline Rerata & 9,290 & 28,273 & 58,102 & 20,265 & 6,431 & 28,273 & 59,197 & 24,303 \\
\hline
\end{tabular}

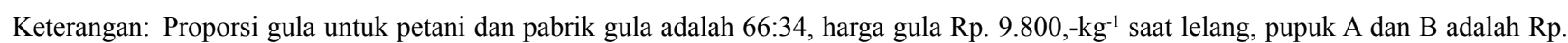
$6,000,-\mathrm{kg}^{-1}$, dan pupuk ZA Rp. 4,500,- $\mathrm{kg}^{-1}$

\section{KESIMPULAN}

Aplikasi paket pupuk formula $16 \mathrm{~N}: 8 \mathrm{P}: 18 \mathrm{~K}: 2 \mathrm{~S}: 2 \mathrm{Si}$ pada sistem tanam juring tunggal, pkp $130 \mathrm{~cm}$ dan $110 \mathrm{~cm}$, menghasilkan produktivitas, rendemen dan habluryang tidak berbeda nyata dengan paket formula $15 \mathrm{~N}: 15 \mathrm{P}: 15 \mathrm{~K}: 10 \mathrm{~S}$, namun pada sistem juring ganda benih ganda pkp 50/170 $\mathrm{cm}$ meningkatkan hasil hablur 9.2\%. Keuntungan yang diperoleh paket pupuk formula $16 \mathrm{~N}: 8 \mathrm{P}: 18 \mathrm{~K}: 2 \mathrm{~S}: 2 \mathrm{Si}$ pada sistem tanam juring tunggal (12.07 juta-14.23 juta rupiah $\mathrm{ha}^{-1}$ ) lebih rendah dibanding paket $15 \mathrm{~N}: 15 \mathrm{P}: 15 \mathrm{~K}: 10 \mathrm{~S}$, namun pada sistem tanam juring ganda benih ganda pkp 
50/170 cm (39.92 juta rupiah ha $\left.\mathrm{ha}^{-1}\right)$ lebih tinggi dibanding paket pupuk formula $15 \mathrm{~N}: 15 \mathrm{P}: 15 \mathrm{~K}: 10 \mathrm{~S}$ (28.49 juta rupiah $\left.\mathrm{ha}^{-1}\right)$.

\section{DAFTAR PUSTAKA}

Ashraf, M.Y., F. Hussain, J. Akhter, A. Gul, M. Ross, G. Ebert. 2008. Effect of different sources and rates of nitrogen and supra optimal level of potassium fertilization on growth, yield and nutrient uptake by sugarcane growth under saline conditions. Pakistan J. Bot. 40:1521-1531.

Brassioli, F.B., R.M. Prado, F.M. Fernandes. 2009. Agronomic evaluation of siderurgy slag in sugarcane during five cycles of production. Bragantia 68:381387.

Dametie, A., A. Fantaye, Z. Teshome. 2012. Correlation of foliar nutrient status with yield of sugarcane varieties at different crop stages and nitrogen levels at WonjiShoa and Finchaa Sugarcane Plantations of Ethiopia. Ethiop. J. Appl. Sci. Technol. 3:9-22.

de Sousa-Vieira, O., S.B. Milligan. 2005. Interrelationships of cane yield components and their utility in sugarcane family selection: path coefficient analysis. Interciencia 30:93-96.

Dev, C.M., R.K. Singh, R.N. Meena, A. Kumar, K. Singh. 2013. Production potential and soil fertility status of ratoon sugarcane (Saccharum officinarum L.) as influenced by time and level of earthing up and nitrogen levels in North-Eastern Uttar Pradesh, India. Sustain. Agric. Res. 2:143-148.

Djumali, A.D. Khuluq, S. Mulyaningsih. 2016. Pertumbuhan dan produktivitas tebu pada beberapa paket tata tanam di lahan kering. J. Agron. Indonesia 44:211-219.

Djumali, S. Mulyaningsih, Lestari. 2014. Perbaikan sistem tanam juring ganda untuk meningkatkan produktivitas tanaman tebu. Balai Penelitian Tanaman Pemanis dan Serat, Malang.

Djajadi. 2013. Silika (Si): Unsur hara penting dan menguntungkan bagi tanaman tebu (Saccharum officinarum L.). Perspektif 12:47-55.

Farooq, M., A. Wahid, N. Kobayashi, D. Fujita, SMA. Basra. 2009. Plant drought stress: Effects, mechanisms and management. Agron. Sustain. Dev. 29:185-212.

Gana, A.K. 2008. Effects of organic and inorganic fertilizers on sugarcane production. Afr. J. General Agric. 4: 55-59.
Inoue, K., I. Yamane, T. Kaji. 2009. Effect of nitrogen topdressing and number of tillers at maximum tillering stage on the field and extract quality of ratoon sugarcane cultivar Ni17. Jpn. J. Soil Sci. Plant Nutr. 80:1-6.

Keeping, M.G., S.A. Mcfarlane, N. Sewpersad, R.S. Rutherford. 2010. Effects of silicon and plant defence inducers on sugarcane yield parameters, Eldana saccharina Walker (Lepidoptera: Pyralidae) and Fulmekiola serrata Kobus (Thysanoptera: Thripidae). Int. Sugar J. 83:271-275.

Kingston, G., M.C. Anink, B.M. Clift, R.N. Beattie. 2009. Potassium management for sugarcane on base saturated soils in Northen New South Wales. Proc. Aust. Soc. Sugar Cane Technol. 31:186-194.

Kumar, N., U.P. Sinha. 2008. Response of spring-planted sugarcane (Saccharum officinarum) to phosporus and sulphur application. Indian J. Agron. 53:145-148.

Matichenkov, V.V., B. Ande, P. Ande, D.V. Calvert, E.A. Bocharnikova. 2002. Effect of silicon-rich slag and lime on phosphorus leaching in sandy soils. J. Amer. Soc. Sugarcane Tech. 22:9-20.

Mateos-Naranjo, E., L. Andrades-Moreno, A.J. Davy. 2013. Silicon alleviates deleterious effects of high salinity on the halophytic grass Spartina densiflora. Plant Physiol. Biochem. 63:115-121.

McCray, J.M., R.W. Rice, Y.G. Luo, S.N. Ji. 2010. Sugarcane response to phosporus fertilizer on everglades Histosols. Agron. J. 102:1468-1477.

Naga-Madhuri, K.V., M.H. Kumar, N.V. Sarala. 2011. Influence of higher doses of nitrogen on yield and quality of early maturing sugarcane varieties. Sugar Tech. 13:96-98.

Nasir, A., G.A. Jariko, M.A. Junejo. 2013. Factors affecting sugarcane production in Pakistan. Pakistan J. Commer. Soc. Sci. 7:128-140.

Nurhayati, A. Basit, Sunawan. 2013. Hasil tebu pertama dan keprasan serta efisiensi penggunaan hara $\mathrm{N}$ dan S akibat substitusi ammonium sulfat. J. Agron. Indonesia 41:54-61.

Otto, R., G.C. Vitti, P.H. de Cerqueira-Luis. 2010. Potassium fertilizer management for sugarcane. Revista Brasileira de Ciencia do Solo 34:1137-1145.

Puslitanah.1987. Kriteria penilaian sifat kimia tanah. Pusat Penelitian Tanah. Bogor. 
Ramadhaini, R.F., Sudrajat, A. Wachjar. 2014. Optimasi dosis pupuk majemuk NPK dan Kalsium pada bibit kelapa sawit (Elaeis guineensis Jacq.) di pembibitan utama. J. Agron. Indonesia 42:52-58.

Singh, K.P., A. Suman, P.N. Singh, M. Lal. 2007. Yield and soil nutrient balance as on a sugarcane plantratoon system with conventional and organic nutrient management in sub-tropical India. Nutr. Cycl. Agroecosys 79:209-219.

Singh, V.K., A.K. Shukla, M.S. Gill, S.K. Sharma, K.N. Tiwari. 2008. Improving sugarcane productivity through balanced nutrition with potassium, sulphur, and magnesium. Better Crops India 24:12-14.

Shukla, S.K., R.C. Yadav, P.N. Singh, I. Singh. 2009. Potassium nutrition for improving stubble bud sprouting, dry matter partitioning, nutrient uptake and winter initiated sugarcane (Saccharum spp. hybrid complex) ratoon yield. Europen J. Agron. 30:27-33.

Tubana, B., C. Narayanaswamy, J. Lofton, Y. Kanke, M. Dalen. L. Datnoff. 2012. Impact of silicon fertilization to sugarcane grown on alluvial soils of Louisiana. J. Amer. Soc. Sugar Cane Technol. $32: 75$.

Vieira, M.X., P.C.O. Trivelin, H.C.J. Franco, R. Otto, C.E. Faroni. 2010. Ammonium chloride as nitrogen source in sugarcane harvested without burning. Revista Bras. Ciencia do Solo 34:1165-1174.

Virdia, H.M., C.L. Patel. 2010. Integrated nutrient management for sugarcane plant-ratoon system. Indian J. Agron. 55:147-151.

Wiedenfeld, B., J. Encisco. 2008. Sugarcane responses to irrigation and nitrogen in semiarid South Texas. Agron. J. 100:665-671.

Wijaya, K.A. 2008. Serapan N dan P tanaman tebu varietas R 579 dan PS 864 sebagai landasan untuk menentukan saat tepat pemupukan N dan P. J. Pertanian Mapeta 11:26-32.

Yukamgo, E., N.W. Yuwono. 2007. Peran silikon sebagai unsur bermanfaat pada tanaman tebu. J. Ilmu Tanah dan Lingkungan. 7:103-116. 